\title{
A Key for Identification of Deltocephaline Genera (Hemiptera: Cicadellidae: Deltocephalinae) Associated with Vegetable Ecosystem in Sri Lanka.
}

\author{
R. Gnaneswaran, K.S. Hemachandra ${ }^{1}$, H.N.P. Wijayagunasekara ${ }^{1}$ and D. Ahangama ${ }^{1}$ \\ Postgraduate Institute of Agriculture \\ University of Peradeniya \\ Peradeniya, Sri Lanka
}

\begin{abstract}
Members of the subfamily Deltocephalinae include many vector species transmitting pathogens among economically important crops. Species of ten genera belonging to seven tribes namely, Exitianus Ball, Nephotettix Matsumura, Deltocephalus Burmeister, Hecalus Stål, Balclutha Kirkaldy, Cicadulina China, Hishimonus Ishihara, Orosius Distant, Changwhania Kwon and Doratulina Melichar were detected in a survey carried out during 2007-2008 in Mid Country associated with the vegetable ecosystems of Sri Lanka. An illustrated dichotomous key based on the morphology and genitalia characters is presented here for easy identification of field collected leafhoppers at generic level.
\end{abstract}

\section{INTRODUCTION}

Deltocepahlinae is the largest subfamily in the family Cicadellidae (leafhoppers), and members of this subfamily occur in all zoogeographic areas and many species are capable of transmitting pathogens among economically important crops. The subfamily is divided into 23 tribes and of these, 9 tribes were reported in Sri Lanka (Omen et.al., 1990). Deltocephalines feed on the phloem sap of a wide variety of vascular plants, and the members of about 14 tribes feed only on grasses or sedges (Viraktamath, 2005a).Of the leafhopper vectors of the plant diseases, $63 \%$ of the species belongs to subfamily Deltocephalinae (Nielson, 1979). The species of Nephotettix Matsumura, Deltocephalus (Recilia) Burmeister, Orosius Distant and Hishimonus Ishihara have been reported as important vectors in India (Viraktamath, 2005a). Study of the species diversity leafhoppers in agroecosystems in Sri Lanka, has revealed 25 species of Deltocephalines belonging to 10 genera in 7 tribes including vector species (Gnaneswaran et al., 2006). Presence of vector species associated with the crop ecosystem must be monitored with care to avoid economic loss in the future. For which all species must be identified correctly. Taxonomic studies of Leafhoppers in Sri Lanka had not been carried out after Distant (1918). Occurrence of the species of some genera namely: Deltocephalus (Racilia), Nephotettix (Gnaneswaran et al., 2008b; Wilson and Claridge, 1991) and Idioscopus (Gnaneswaran et al., 2007) were reported from Sri Lanka with taxonomic notes but not other genera. There is a great need to develop illustrated simple keys to vectors and other economically important species of leafhoppers for use by entomologists who are dealing with crop protection strategies. 


\section{MATERIALS AND METHODS}

A field survey was conducted in vegetable ecosystems selected in Mid Country Wet Zone and Low Country Dry Zone of Sri Lanka, during 2007-2008 to collect leafhoppers from vegetables and grasses. The insect specimens were collected by using sweep nets and aspirators. The collected specimens were curated (Oman et al., 1949) and deltopcephalines were sorted out by examining their morphological characters (Viraktamath, 2005a \& b) under binocular stereoscopic microscope (X 10) and mounted singly on card points. The abdomen of each specimen was dissected to study the genitalia (Knight, 1965) and then identified by consulting published taxonomic keys and related literatures (Morrison, 1973; Webb, 1987; Rao and Ramakrishnan, 1990; Dietrich, 2005 and Viraktamath, 2005 a \& b).

Identities of the specimens were confirmed by Dr. C. A. Viraktamath, Department of Entomology University of Agricultural Sciences, Bangalore, India. A key to the Deltocephaline genera associated with vegetable ecosystem in mid country Sri Lanka, was prepared based on the morphological variations.

\section{RESULTS AND DISCUSSION}

Seventeen species of Deltocephaline leafhoppers namely Balclutha incisa (Matsumura), Changwhania ceylonensis (Baker), Cicadulina bipunctata (Melichar), Deltocephalus (R) distinctus Motschulsky, Deltocephalus (R) porticus Melichar, Doratulina indra (Distant) ,Doratulina jacosa Melichar, Exitianus indicus (Distant), Exitianus nanus (Distant), Hecalus arcuatus (Motschulsky), Hecalus porectus (Walker), Hecalus ghaurii Rao \& Ramakrishnan, Hishimonus phycitis (Distant), Nephotettix nigropictus (Stal), Nephotettix parvas Ishihara \& Kiwase, Nephotettix virescencs (Distant) and Deltocephalus $(R)$ dorsalis (Motschulsky) belong to 10 genera of 7 tribes were identified from the samples collected from Vegetable ecosystems in mid country of Sri Lanka, during the survey period (Gnaneswaran, 2006).

Although considerable damage was noticed on vegetable crops by the species of typhlocybine leafhopper (Gnaneswaran et al., 2008a), no damage symptoms were observed due to the presence of Deltocephaline species. Several of the well known vector species were found in very few numbers. They were: Hishimonus phycitis (Distant) was collected from brinjal (7/field) which has been known to transmit phytoplasma which causes little leaf of brinjal (Nielson, 1979), and Orosius albicinctus Distant, a vector for Phyllody of sesame and gram, and potato purple top roll in brinjal, collected by sweeping grasses in the ecosystem (2/field). Deltocephalus dorsalis (Motschulsky) a vector of rice stunt disease and Cicadulina bipunctata (Melichar) vector for ragi streak virus.

Regular monitoring of these vector species is essential in this ecosystem in order to forecast and minimize the damage. Therefore, a simplified taxonomic key is prepared for a correct identification of the species which is a pre prerequisite for easy monitoring and manipulation of this group of insect.

\section{Key to separate leafhopper genera associated with vegetable ecosystem in mid country region of Sri Lanka (after Viraktamath 2005 a \& b).}

Deltocephalinae. Small to medium sized insects $(2-8 \mathrm{~mm})$ with ocelli either on anterior margin of head or close to anterior margin of head on crown of vertex . Clypeus not extended laterally over bases of antennae to form antennal pits. In Macropterous form front wing possess cross vein $\mathrm{r}-\mathrm{m} 1$. 
1 Front wings with 2 anteapical cells (Fig.1a). $\quad 2$

- Fore wings with 3 anteapical cells cross vein present (Fig. 1a)

2 Connective racket shaped with anterior arms close to each other/fused (Fig. 1d)

Slender aedeagus, with asymmetrical process; -Paralimnini head with two black spots.

- Connective 'Y' shaped with anterior arms separated widely (Fig. 1e); Adeagus with shaft fused to base; $10^{\text {th }}$ segment membranous -

Macrostelini

3 Vertex of head with uniform length; hind basitarsus basally emarginated (Fig. 1g); slender.

- Vertex of head longer medially than next to eyes head and thorax ochraceous; two black dots on vertex. . hind basitarsus basally not emarginated.

4 Body depressed; head strongly produced; ocelli on crown near margin, very close to eyes.- Hecalinii

Face and thorax green to yellowish green with Concentric parabolic orange fasciae on head and pronotum.

- Body more or less cylindrical head not much produced. ocelli and antennal bases much closer to eyes than apex of crown.

Changwhania Kwon

5 Male subgenital plate separate: (Fig. 1f) Aedeagal shaft paired with pair gonopore (Fig.1f; gp). Shaft either completely divided or bifid apically- Opsiini

- Male subgenital plate separate; Adeagal shaft single with one gonopore (Fig. 1i; gp). Male connective articulated to aedeagus; Anterior arms of connective free distally.

Hecalus Stål

Balclutha Kirkaldy

Cicadulina China

6 Forewing claval veins fused medially (Fig. 1b; clv); coloration creamy white with brown spots.

Forewing claval veins connected by cross vein (Figure 2; cv), colouration variable; Fore wing maculate with well defined discal semicircular spot (Fig. 1k). Aedeagus has no ventral process.

Hishimonus Ishihara

7 Male connective linear fused to aedeagus Deltocephalini

Stout body. vertex more than twice as broad as long male plate fused at the base linear male connective, fused to aedeagus.

Deltocephalus Burmeister

- Male connective Y shaped articulated with aedeagus

8 Male pygophore with dorsal margin sloping downwards; Ovipositor much elongated. -Stenometopiini Male pygophore without a dorsal process.

Doratulina Melichar

- Male pygophore with dorsal margin more or less horizontal (Fig. 1j): ovipositor not much elongate - Chiasmini Brown or ochraceous with black markings. Green colour with black markings. 


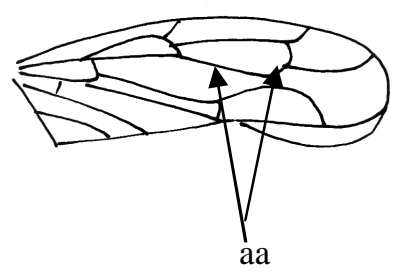

a

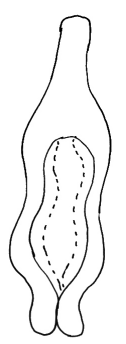

d

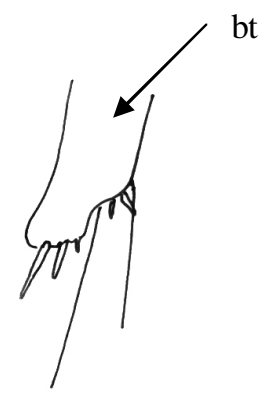

g

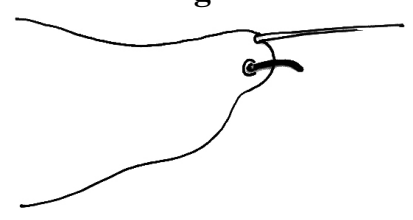

j

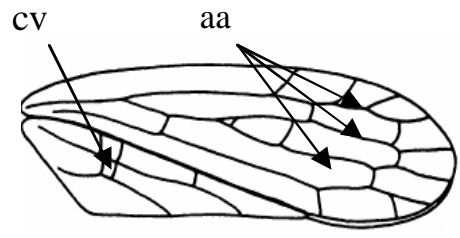

calve

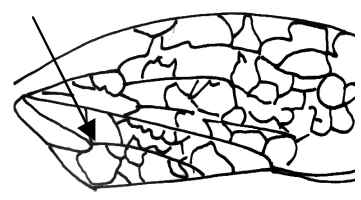

c

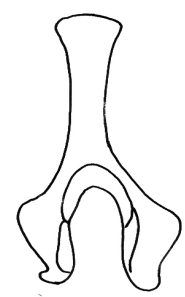

e

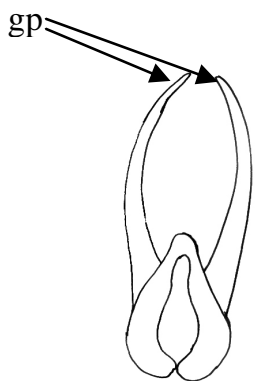

h

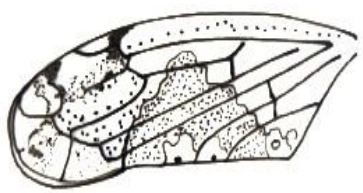

$\mathbf{k}$

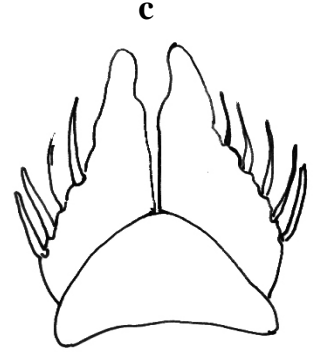

f

gp

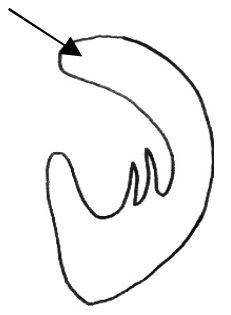

i

Fig. 1. 12 Structures of Deltocephaline leafhoppers living in association with vegetable ecosystems in Sri Lanka.

a. Forewing of Cicadulina bipunctata (Melichar); b. Forewing of Hecalus porectus (Walker); .

c. Forewing of Orosius albicinctus Distant; d. Male connective of Changwhania ceylonensis (Baker); e. Male connective of C.bipunctata (Melichar); f. Subgenital plate of Deltocephalus (R) porticus (Melichar); g. Basitarsus of Balclutha incisa (Matsumura); h. Aedeagus of Hishimonus phycitis (Distant); i. Aegeagus of Exitianus indicus (Distant); j. Pygofer of the same; k. Forewing of $H$. phycitis (Distant). 


\section{ACKNOWLEDGEMENTS}

The Sri Lanka Council for Agricultural Research Policy (CARP) is acknowledged for funding (12/668/504). The authors are grateful to Dr. C.A .Viraktamath, UAS, Bangalore, India for the confirmation of the identification and to Mr. UGLT Gunawardana, for assistance in field collection.

\section{REFERENCES}

Dietrich, C.H. (2005). Keys to the families of Cicadomorpha and subfamilies and tribes of Cicadellidae (Hemiptera: Auchenorhyncha). Flo. Entomol. 88: 502 - 517.

Distant, W.L. (1918). The fauna of British India - Ceylon and Burma. Rhynchota Vol VII Heteroptera, Taylor and Francis, London, UK. Appendix. viii, pp.210.

Gnaneswaran, R., Hemachandra, K.S., Ahangama, D., Wijayagunasekara, H.N.P. and Wahundeniya, I. (2006). Diversity of Leafhoppers (Hemiptera: Auchenorhyncha: Cicadellidae) Associated with paddy and Vegetable ecosystems in Mid Country of Sri Lanka. Sri Lankan J. Agric. Sci. 43-133-143.

Gnaneswaran,R. K.S. Hemachandra, C.A. Viraktamath, D. Ahangama, H.N.P.

Wijayagunasekara I. Wahundeniya (2007). Idioscopus nagpurensis (Pruthi) (Hemiptera: Cicadellidae: Idiocerinae): A New Member of Mango Leafhopper Complex in Sri Lanka. Tropical Agricultural Research 19: 78 - 90

Gnaneswaran, R., Viraktamath, C.A. Hemachandra, K.S., Ahangama, D., Wijayagunasekara, H.N.P. and Wahundeniya, I. (2008a). Typhlocybine leafhoppers (Hemiptera: Auchenorhyncha : Cicadellidae) associated with horticultural crops in Sri Lanka. Tropical Agric. Res. 20:1-12.

Gnaneswaran, R., K.S. Hemachandra, D. Ahangama and H.N.P. Wijayagunasekara and Wahundeniya, I (2008b). Species of Nephotettix Matsumura (Hemiptera: Auchenorhyncha: Cicadellidae) in Sri Lanka. Short communication: Tropical. Agri. Res. 20:414-418

Knight, W.J. (1965). Techniques for use in the identification of Leafhoppers (Homoptera: Cicadellidae). Ent. Gaz. 16: 129 - 136.

Morrison, W.P. (1973). A revision of the Hecalinae (Homoptera: Cicadellidae) of the Oriental Region. Pacific Insects 15: 379-438.

Nielson, M.W. (1979). Taxonomic relationship of leafhopper vectors of plant pathogens In. Maramarosh, K and Harris, K. (Eds.) Leafhopper vectors and plant disease agents. Academic Press, NY 3 - 27.

Oman, P. W. (1949). The Nearctic leafhoppers (Homoptera: Cicadellidae): a generic classification and check list. Mem. Entomol. Soc. Washington 3: 1-253.

Rao, R.V. and Ramakrishnan, U. (1990). The Indian species of Hecalus with descriptions of three new species (Homoptera: Cicadellidae). Oriental Insects 24: 385 - 397. 
Viraktamath, C.A. (2005a). Key to the subfamilies and tribes of leafhoppers (Hemiptera; Cicadellidae) of the Indian Subcontinent. Bionotes 7(1): 20 - 24.

Viraktamath, C.A. (2005b). Key to the subfamilies and tribes of leafhoppers (Hemiptera; Cicadellidae) of the Indian Subcontinent. Bionotes 7(2): $44-49$.

Webb, M.D. (1987). Species recognition in Cicadulina leafhoppers (Hemiptera: Cicadellidae), vectors of pathogens in Gramineae. Bull. Entomol. Res. 77: 683 -712.

Wilson, M.R. and Claridge, M.F. (1991). Handbook for the Identification of Leafhoppers and Planthoppers of Rice. CAB International for International Institute of Entomology in association with Natural Resources Institute, London, UK. 